\title{
Misconduct in Contract Negotiations as the Basis for Compensation of Losses
}

\author{
Tamara V. Shepel* \\ Novosibirsk National Research State University \\ 1 Pirogova Str., Novosibirsk, 630090, Russia
}

Received 05.06.2016, received in revised form 09.07.2016, accepted 27.08.2016

\begin{abstract}
Article 434.1. of the Civil Code of the Russian Federation considers the misconduct during contract negotiationsto be the basis for civil liability in the form of losses compensation. However, the legislator does not define the concept of bad faith and its place among the constituent elements of the violation of law, which in the Russian legislation, doctrine and legal practice is traditionally recognized as the basis for liability. The purpose of this article is to address the task relevant for the development of Russian civil law and law enforcement practice: to determine the nature of bad faith of the party in the course of or failure of contract negotiations, its relation to culpability as a condition for the traditional civil liability. The research allows to conclude that bad faith of the party during negotiations cannot be an independent condition (element) of an offense. The article gives a critical analysis of the Resolution No. 7 of the Supreme Court Plenum "On application by the courts of certain provisions of the Civil Code on liability for breach of obligations"dated March 24, 2016, in the part of clarification of the rules on the conditions of civil liability under Article 434.1. of the Civil Code.
\end{abstract}

Keywords: basis for civil liability, culpability, bad faith, pre-contractual liability.

DOI: 10.17516/1997-1370-2016-9-9-2288-2294.

Research area: Civil law; entrepreneurial law; family law; international private law.

Civil law provides for various forms of civil liability: contractual penalty, interest on borrowed funds, compensation for moral harm, deprivation of property rights, etc. But the civil doctrine and law enforcement practice recognize losses as a universal form of the civil law liability.

The Federal law N 42-FZ "On Amendments to Part One of the Civil Code of the Russian Federation" dated March 08, 2015, has expanded the scope of compensation of losses. In particular, it assigns for additional basis for compensation of losses caused in the pre-contractual legal relationships: a) in case the assurance of the circumstances relevant to the contract, its execution or termination is unreliable (Article 431.2 of the Civil Code of the Russian Federation); b) in case the contract negotiation is unfair or interrupted, as well as in case of the disclosure of confidential information or use it for their own purposes (par. 3 and par. 4, Art. 434.1. of the Civil Code).

Despite the variety of rules regarding losses, the legislator does not specify the basis and conditions of their compensation. Unfortunately,

(C) Siberian Federal University. All rights reserved

* Corresponding author E-mail address: tomaser@mail.ru 
the Civil Code does not provide for general rules of civil liability, including the grounds for its appearance. Chapter 25 of the Civil Code cannot be considered as a chapter containing general provisions on civil liability, which has been repeatedly discussed in the civil law literature.

Civil jurisprudence traditionally connects civil liability with the violation of law. Of course, in the conditions of rapidly developing economic relations, liability rules in Russia cannot remain unchanged. But we must not forget that the expansion of the scope of rules on liability, including civil law, should be based on fundamental universal structures, which include legal responsibility and its basis. Therefore, V.F. Iakovlev warns against excessive expansion of civil liability limits. According to him, "for liability issues to be resolved correctly, both the legislator and law enforcer should proceed from the fact that there is a general notion of liability as a general legal category ... Of course, liability is putting unfavourable measures on a person who had violated the law, but not each encumbrance is a responsibility, but only that which arises in connection with the violation of the law" (Iakovlev, V.F., 2014).

Resolution No. 7 of the Plenum of the Supreme Court "On application by the courts of certain provisions of the Civil Code on liability for breach of obligations" dated March 24, 2016, for the first time explaining the general provisions on civil liability, confirms the traditional approach to its basis and conditions. Subparagraph 1 Paragraph 5 of the Resolution states that within the meaning of Articles 15 and 393 of the Civil Code, the creditor provides evidence of their losses and the causal link between the failure to perform or improper performance of the obligations by the debtor and the named losses. Subparagraph 4 of the same paragraph states that the debtor's fault in violation of the obligations is assumed, until proven otherwise. The absence of guilt in the non-fulfillment or improper fulfillment of the obligations can be proved by the debtor (Par. 2, Art. 401 of the Civil Code). It is important to note that the Resolution does not question the existence of liability without fault. According to subparagraph 5 of the analyzed paragraph, "if the debtor is liable for the breach of an obligation or causing harm, regardless of culpability they bear the responsibility for proving the circumstances constituting the grounds for exemption from liability (Par. 3 of Art. 401 of the Civil Code) [Shepel, T.V., p. 5]. The analysis of Paragraph 5 of the Resolution unambiguously shows that the Supreme Court recognizes the basis for civil liability, regardless of its type and form, as full composition of the offense, with the exception of liability regardless of culpability.

Previously, the same approach to the basis for losses compensation was set out in Paragraph 12 of the Resolution No. 25 of the Plenum of the Supreme Court of the Russian Federation "On application by the courts of some of the provisions of Section 1 of the Civil Code of the Russian Federation" dated June 23, 2015, which specifies all the conditions (elements of the structure) of the law violation required for compensation of losses. In particular, subparagraph 1 of this paragraph states that "the plaintiff must prove that the defendant is a person, whose actions (absence of actions) have resulted in the damage, as well as facts of violation of obligations or damage, the presence of damage (Paragraph 2 of Article 15 of the Civil Code the Russian Federation). Subparagraphs 3 and 4 of the same paragraph state the rule of guilt as a compulsory condition of civil liability, which is assumed until proven otherwise. If the person is responsible for the breach of an obligation or causing harm, regardless of culpability, then they bear the burden of proving the circumstances constituting the basis for exemption from liability. 
Article 434.1 of the Civil Code introduced by the Federal Law N42 dated March 08, 2015 states that the basis for compensation of losses is a misconduct. According to Paragraph 3 of this Article, a party, who negotiates or breaks off contract negotiations in bad faith, is obliged to compensate incurred losses to the other party. There is quite a legitimate question: whether the misconduct is an offense or the legislator establishes another basis for liability for the failure of negotiations instead of the violation.

Setting of the principle of good faith in Article 1 of the Civil Code has intensified the studies of this fundamental and multiconceptual category in scientific literature. Scholars note the complexity of determining its nature and field of application, due to the lack of legal definition and specification of legal effect for all areas of action (establishment, implementation and protection of civil rights and civil obligations).

The absence of a legislative definition of good faith contributes to the occurrence of many positions regarding the nature of good faith. Currently, there are three main approaches to understanding of good faith: 1) according to the objective (moral) approach acting in good faith should be evaluated with the help of moral categories of honest acting, compliance with the requirements of good faith, respect for a fair balance of interests of the individual and society (Agarkov, M.M., Bogdanova, E.E., Rizhenkov, A.Ya, Shchennikova, L.V., etc.); 2) supporters of the subjective approach consider good faith as a special willful attitude, when a person was not and should not have been aware of the circumstances, the occurrence of which involves legal consequences. In other words, they consider good faith as an analogue of innocence (culpability) (Petrazhitskii, L.I.; Em, V.S.; Krasnova, S.V. et al.); 3) the mixed approach recognizes the existence of good faith in the objective and the subjective sense (Novitskii, I.B.,
Suleimenov, M.K., Golubtsov, V.G.; Drozdova, T..Yu.; Primak, V.D. et al.).

The antipode of good faith is bad faith. The concept of bad faith in the Civil Code of the Russian Federation, unfortunately, is also missing. Accordingly, the nature of bad faith can be evaluated in terms of the above given approaches. As an objective category, it is the violation of moral and ethical principles of a good conscience, honest doing of things, balance of the interests of the individual and society. In the subjective sense, bad faith is understood as a willful attitude, when a person was or should have been aware of the circumstances that have negative legal consequences. The mixed approach to the understanding of the misconduct is also possible, combining objective and subjective characteristics.

It seems that the mixed approach to the definition of the nature of good faith (bad faith) is most relevant to today's realias: civil relationships in which the law applies these categories are very diverse. Their objective or subjective understanding should be given the priority, depending from the perspective of which civil law institutions they are considered (Golubtsov, V.G., 2016).

The Civil Code of the Russian Federation in several cases recognizes the misconduct as the basis for compensation of losses. Thus, in accordance with Par. 3 of Art. 220 of the Civil Code in case of unfair actions of a person in charge of dealing with other person's property, the owner is entitled to claim compensation of damages caused to them. When getting the property back from illegal possession, the owner may also claim refund or reimbursement of all incomes that were earned, or should have been earned during possession from the person who was or should have been aware that the possession was illegal (illegal owner) (Article 303 of the Civil Code). The party who negotiates or breaks 
off contract negotiations in bad faith, is obliged to compensate the other party the losses caused therein (par. 3 of Art. 434.1. of the Civil Code).

In some cases, the Civil Code directly states that culpability is the condition for compensation, such as "non-contractual losses". Thus, in accordance with Par. 4, Art. 227 of the Civil Code, the person who has found the thing is responsible for its loss or damage only in case of an intent or gross negligence. However, this rule is rather an exception than the general rule. Typically, the obligatoriness of culpability in case of compensating non-contractual losses is concluded from other legislative definitions: groundless avoidance of notarization or state registration of the transaction (Paragraph 3 of Article 165 of the Civil Code); awareness of the party concluding a contract (either before or after its conclusion) of mispresentation of the circumstances or that the other party would rely on such mispresentation (Subparagraph 2, Paragraph 4, Article 431.2. of the Civil Code). Sometimes the legislator recognizes the subjective condition for compensation of losses beyond the contract as the condition for a person, when they knew or should have known about the violation of the transaction terms at the time of its conclusion, i.e. their guilt. Therefore, the legally capable party of the transaction is obliged to compensate the real damage to the other party in full or in part, if the legally capable party knew or should have known of the defects of the transaction (Subpar. 3, Par. 1, Art. 171, Subpar. 2 Par. 1, Art. 175, Subpar. 2 Par. 1, Art. 176, Par. 3, Art. 177, Par. 4, Art. 179 of the Civil Code).

Such inconsistency in definitions, of course, does not contribute to the formation of a uniform law enforcement practice, which traditionally recognizes the violation of law rather than misconduct as the basis for compensation of losses, including those arising from beyond the contract. We cannot consider the misconduct not through the prism of the violation. Recognition of the subject's misconduct as an independent basis for liability, apart from the violation, ignores the peculiarities of the national civil law.

Nevertheless, the analysis of the Russian Federation Civil Code rules allows to conclude that the legislator, as a general rule, recognizes culpability as a mandatory condition for compensation of losses, although uses different terminology to refer to it, including calling it bad faith. When bringing the offender to civil liability, their bad faith, in our opinion, should be assessed primarily as culpability, i.e. particular negative mental attitude towards their actions and the results, when they knew or should have known about the facts of the reality.

The definition from Paragraph 2 Article 434.1. of the Civil Code of the Russian Federation proves this conclusion:

Firstly, specifying the conditions for fair conduct of the parties when entering into contract negotiations, the legislator refers to the form of culpability in case of breaking off the negotiations; in particular, it is unacceptable to start contract negotiations with the known absence of intention to reach an agreement. "Known" cannot be interpreted otherwise than intentional.

Secondly, the cases of presumption of bad faith in negotiations mentioned in this paragraph largely relate to the psychological characteristics of the parties' conduct, for example, nondisclosure of the circumstances, which due to the contract nature must be communicated to the other party.

Thirdly, if we recognize the conclusions of some authors that the negative attitude of the offender is outwardly expressed in not taking measures of care and diligence necessary in accordance with the civil law (Belov, V.A., 2011; Shepel, T.V., 2014), it is permissible to consider other circumstances specified in Subparagraphs 1 and 2, Par. 2, Art. 434.1. Civil Code as the 
manifestation of culpability: a) provision of the incomplete or inaccurate information; b) sudden and unjustified termination of contract negotiations under such circumstances, which the other negotiating party could not reasonably have expected.

Meanwhile, Subparagraph 2 Paragraph 19 of the Resolution No. 7 of the Plenum of the Supreme Court "On application by the courts of certain provisions of the Civil Code on liability for breach of obligations" dated March 24, 2016, contains the following explanation: "it is assumed that each party acts in good faith and termination of negotiations without giving reasons is not a sign of bad faith of the respective side. The plaintiff has the burden of proving that, when entering into negotiations, the defendant acted in bad faith with the purpose of causing harm to the plaintiff, for example, trying to get commercial information from the plaintiff or impede the conclusion of the contract between the plaintiff and a third party (Paragraph 5 Article 10, Paragraph 1 Article 421 and Paragraph 1 Article $434^{1}$ of the Civil Code). Herewith, the rule of Paragraph 2 Article 1064 of the Civil Code does not apply".

This explanation contradicts the rules of civil law regarding the basis and terms of both contract (Article 401 of the Civil Code) and delictual liability (Article 1064 of the Civil Code.); prevailing ideas about them in the civil doctrine; legal practice.

1. The categorical statement to exclude the application of Par. 2, Art. 1064 of the Civil Code to pre-contractual liability, in fact, means abandoning the traditional structure of the violation as the basis of civil liability. The Plenum considers such basis to be the misconduct instead of the violation! Paragraph 2 Article 1064 of the Civil Code states that "a person who caused the damage, shall be exempt from compensation for the damage if they prove that the damage was caused not due to their fault. Law can provide for compensation for the damage and in the absence of fault the wrongdoer". This explanation clearly shows that the Supreme Court of the Russian Federation does not regard culpability as a condition for liability under Article 434.1 of the Civil Code; it also rejects no-fault liability.

One could have agreed with the explanation of the Supreme Court Plenum if it was possible to use not only the first sentence of this paragraph: "a person who caused the damage, shall be exempt from compensation for the damage if they prove that the damage was caused not due to their fault". Then we can say that liability for the failure of the negotiations is another case civil liability regardless of fault set by the law based on the truncated set of elements of the violation. But the paradox is that the highest court considers it necessary to exclude the application of paragraph 2 Article 1064 of the Civil Code in full. In other words, the Plenum rejects the possibility of applying liability for the failure of negotiations and no-fault liability.

Thus, the explanation being analyzed destroys the traditional structure of the offense as the basis for civil liability and offers another basis instead - a misconduct. It seems that the current civil law does not provide for liability for the reasons other than the offense. In Chapter 59 of the Civil Code there are no references to other grounds of dilictual liability. For the contractual liability no other grounds but the offense are also provided. Nevertheless, it should be noted that Paragraph 1 of Article 401 of the Civil Code includes other grounds for liability: "a person who has not performed obligations or performed them improperly shall be liable in the presence of culpability (intent or negligence), unless the law or the contract provide for other grounds for liability". However, other basis in the educational and scientific literature traditionally includes liability regardless of culpability; liability for the guilt of others; special conditions of liability 
under the contract; responsibility only in case of intent or gross negligence of the offender, etc. Thus, the other grounds of civil liability require expansion or narrowing of the basis for liability compared to the liability for the guilt, but not replacement of the offense as the basis for liability.

2. In accordance with Subparagraph 1 Paragraph 19 of the given Resolution, the relations connected with damage caused by misconduct in negotiations are regulated by the rule of law provided in Chapter 59, with the exceptions established in Article 434.1 of the Civil Code. Careful analysis suggests that there are no such exceptions therein. Provided for by Paragraph 6 of this rule on non-application of the provisions on liability in the form of damage for the failure of the negotiations to the citizens, recognized by consumers, it is hardly possible to recognize it as such an exception. In this case, we are not talking about non-application of Chapter 59, but about the general exclusion of liability, no matter what rules of the Civil Code are applicable to it. Thus, the Civil Code does not establish exceptions to Paragraph 8 of this article on the application rules of Chapter 59 of this Code to relations arising from contractual obligations. The reference to this Chapter in the
Resolution of the Plenum analyzed in this article pointing to impossibility of applying paragraph 2 of Article 1064 of the Civil Code in the case of the failure of negotiation is no more than a stretch.

3. The analyzed statement does not correspond to Subparagraphs 4 and 5 of Paragraph 5 of the same Resolution of the Supreme Court Plenum, which confirms that the debtor's guilt is a condition for liability, but there can be liability regardless culpability. Moreover, this paragraph of explanation, as well as paragraphs from 1 to 14 are placed in the Resolution's section dedicated to the general provisions on liability and compensation of losses, which allows to apply them to all types of civil liability, including the failure of negotiations. It seems that the Plenum of the Supreme Court in the case of responsibility for the failure of negotiations had overestimated the value of bad faith category.

Thus, the last sentence of Subparagraph 2 Paragraph 19 of the Resolution No. 7 of the Supreme Court Plenum "On application by the courts of certain provisions of the Civil Code on liability for breach of obligations" dated March 24, 2016, is contrary to the Civil Code of the Russian Federation and should be excluded from the text of the Resolution.

\section{References}

Golubtsov, V.G. (2016). Printsip dobrosovestnosti kak element pravovogo stimulirovaniia dolzhnika k nadlezhashchemu ispolneniiu obiazatel'stv i garantirovaniia interesov kreditorov: analiz sudebno - arbitrazhnoi praktiki [The principle of good faith as an element of legal incentives for the proper performance of the debtor's obligations and support of the interests of creditors: analysis of arbitration practice], In Vestnik Permskogo universiteta. Iuridicheskie nauki. [Perm University Bulletin. Jurisprudence]. 32, 175 - 184.

Belov, V.A. (2011). Praktika primeneniia Grazhdanskogo kodeksa RF chasti pervoi [The practice of the Civil Code of the Russian Federation, Part One], Moscow, Izdatel'stvo Iurait-Izdat, $1301 \mathrm{p}$.

Shepel, T.V. (2014). Vina v grazhdanskom prave: zakonodatel'stvo i tsivilisticheskaia doktrina [Culpability in civil law: law and civil doctrine], In Vestnik Novosibirskogo gosudarstvennogo universiteta. Seriia Pravo [Bulletin of the Novosibirsk State University. Series: Right]. $2,50-55$. 
Iakovlev, V. F. (2014). O poniatii pravovoi otvetstvennosti [On the concept of legal liability], In Zhurnal rossiiskogo prava [Journal of Russian Law]. 1, 5-7.

\title{
Недобросовестное поведение
}

при проведении переговоров

\author{
о заключении договора
}

как основание возмещения убытков

т. Шепель

Новосибирский национальный исследовательский государственный университет

Россия, 630090, Новосибирск, ул. Пирогова, 1

В cm. 434.1. Гражданского кодекса Российской Федерации недобросовестное поведение стороны при ведении переговоров о заключении договора названо в качестве основания гражданскоправовой ответственности в форме возмещения убытков. Однако законодатель не определяет понятие недобросовестности и её место среди элементов состава гражданского правонарушения, которое в российском законодательстве, доктрине и правоприменительной практике традиционно признается основанием ответственности. Цель статьи состоит в решении имеющей значение для развития российского гражданского права и правоприменительной практики задачи - определение природы недобросовестности стороны при ведении или перерыве переговоров, её соотношение с виной как традиционым условием гражданскоправовой ответственности. В результате исследования сформулирован вывод о том, что недобросовестность стороны при ведении переговоров не является самостоятельным условием (элементом) правонарушения. Дан критический анализ Постановления Пленума Верховного суда РФ от 24 марта 2016 г. № 7 «О применении судами некоторых положений Гражданского кодекса РФ об ответственности за нарушение обязательств» в части разъяснений правил об условиях гражданско-правовой ответственности по ст. 434.1. ГК РФ.

Ключевые слова: основание гражданско-правовой ответственности, вина, недобросовестность, преддоговорная ответственность.

Научная специальность: 12.00 .03 - гражданское право; предпринимательское право; семейное право; международное частное право 